Cahiers $d u$ MONDE RUSSE

\section{Cahiers du monde russe}

Russie - Empire russe - Union soviétique et États indépendants

$41 / 1 \mid 2000$

Varia

\title{
Hijra and forced migration from nineteenth- century Russia to the Ottoman Empire
}

A critical analysis of the Great Tatar emigration of 1860-1861

Brian Glyn Williams

\section{(2) OpenEdition}

Journals

Electronic version

URL: https://journals. openedition.org/monderusse/39

DOI: $10.4000 /$ monderusse.39

ISSN: $1777-5388$

Publisher

Éditions de l'EHESS

\section{Printed version}

Date of publication: 1 January 2000

Number of pages: $79-108$

ISBN: 2-7132-1353-3

ISSN: $1252-6576$

\section{Electronic reference}

Brian Glyn Williams, "Hijra and forced migration from nineteenth-century Russia to the Ottoman

Empire", Cahiers du monde russe [Online], 41/1 | 2000, Online since 15 January 2007, connection on 03 September 2022. URL: http://journals.openedition.org/monderusse/39; DOI: https://doi.org/10.4000/ monderusse.39 


\title{
HIJRA AND FORCED MIGRATION FROM NINETEENTH-CENTURY RUSSIA TO THE OTTOMAN EMPIRE
}

\author{
A critical analysis of the Great Crimean Tatar emigration \\ of 1860-1861
}

THE LARGEST EXAMPLES OF FORCED MIGRATIONS in Europe since the World War II era have involved the expulsion of Muslim ethnic groups from their homelands by Orthodox Slavs. Hundreds of thousands of Bulgarian Turks were expelled from Bulgaria by Todor Zhivkov's communist regime during the late 1980s; hundreds of thousands of Bosniacs were cleansed from their lands by Republika Srbska forces in the mid-1990s; and, most recently, close to half a million Kosovar Muslims have been forced from their lands by Yugoslav forces in Kosovo in Spring of 1999. This process can be seen as a continuation of the "Great Retreat" of Muslim ethnies from the Balkans, Pontic rim and Caucasus related to the nineteenth-century collapse of Ottoman Muslim power in this region. The first "dominoe" to fall in this historic process of retreat by former Ottoman Muslim populations was a small TurcoMuslim ethnic group known as the Crimean Tatars. An analysis of the Crimean Tatar mass migrations from the Russian Empire to the Ottoman Empire in the nineteenth century can shed some light on the process that has seen millions of Muslims uprooted and forced to migrate to the Muslim core of the Otttoman Empire, Anatolia. To understand the migration of the Crimean Tatars one must go back to the period of the Crimean War.

In the aftermath of the Crimean War of 1853-1856 approximately 200,000 Crimean Tatars from a total population of roughly 300,000 living in the Russian Empire's Tauride Province (the Crimean peninsula and neighboring steppe lands) abandoned their ancestral lands and migrated to the Ottoman Empire in a process known as hijra (religious migration). The strange mass movement of two 
thirds of this Muslim people from their ancestral lands to the ak toprak ("white soil", i.e. sacred land) of the Ottoman caliph-sultan is one of the least understood migrations related to Russian colonial rule in the Muslim borderlands.

While this migration can be seen in part as a sub-plot to the Great Retreat of Muslim ethnies such as the Circassians, Ubykhs, Abkhazians, Chechens, Nogais, Bosniacs, Pomaks, Balkan Turks, Laz and other Muslim groups related to the nineteenth-century collapse of Muslim rule in the Balkans, the Pontic rim and the Caucasus, this movement had its own peculiar dynamics. As will be demonstrated, this little understood migration was partially the result of colonial policies specific to the Tauride province and internal mechanisms working within nineteenthcentury Crimean Muslim society. In addition, events surrounding the Crimean War, which was fought across the lands of Crimea long settled by Tatar peasants, acted as a catalyst for this mass emigration. In order to understand the background to this migration, which took place between 1859 and 1862, one must in fact look back to the Crimean Tatars' position during the Crimean War.

There are considerable differences of opinion between many nineteenth-century tsarist officials and Soviet propagandists on one side and the Crimean Tatars and their sympathizers (many of whom were Russian) on the other side concerning the Crimean Tatars' role during the Crimean War. General Menshikov (the commander of the Crimean front during the Crimean War) and several Soviet historians have generally depicted the Crimean Tatars as traitors to the Russian rodina (homeland) during this conflict. The Crimean Tatars' communal betrayal of Russia during this war is presented in many post-1944 sources as a rehearsal for this nation's later "mass betrayal" of the Soviet Union during World War II. P. N. Nadinskii's work Essays on the history of the Crimea (Ocherki po istorii Kryma), published just seven years after the deportation of the entire Crimean Tatar nation in 1944, is considered a classic of historical revisionism and generally paints a negative picture of the Crimean Tatars.

In this work Nadinskii writes "The massive migration of the Tatars to Turkey also appeared as a direct response to the war. The main cause of this emigration was the Tatars' fear of just retribution for their traitorous behavior during the war."1 It was, according to this popular viewpoint, the Crimean Tatars" "fanatical" attachment to their co-religionists, the Turks, that led this people into collusion with the Ottomans and their allies during the Crimean War. At the conclusion of the war, according to anti-Tatar accounts, the Crimea's Muslim population, in a religious frenzy, abandoned the Russian Empire in a mass migration to join their Muslim allies in the Ottoman Empire.

On the other hand, the Crimean Tatars and their sympathizers stress this people's loyalty during the Crimean War and claim that they were actually the passive victims of Russian attacks during the conflict. A nineteenth-century Russian writer living in the Crimea, Evgenii Markov, claims that the Russian populace of the Crimea (as opposed to the officials in far off St. Petersburg) felt that 
the Crimean Tatars had actually been loyal during the war. According to this source "With one voice they say that, without the Tatars, we would have fallen; all means of transport were exclusively in their hands." 2 A second Russian source, G. I. Levitskii claims that "All this slander and censure" against the Crimean Tatars was an obvious pretext by those not familiar with the Crimea or its Tatar inhabitants to rid this territory of its Muslim population. ${ }^{3}$

General Totleben, the defender of Sevastopol during the Allied French, British, Ottoman and Sardinian invasion of the Crimea (1854-1856), mentions that relations between the Russian peasants and Muslim Tatars of the Crimea during the war were friendly and writes: "Between the Russians and Tatars there is no noticeable mutual hatred and our simple people now are extraordinarily regretful about the departure of the latter." 4 From London, the exiled Russian writer Alexander Herzen wrote:

"The general opinion of all those who know the Crimea is unanimously in favor of the Tatars. This people is quiet and submissive and does not have any sort of prejudice against the Russian government, in spite of all the oppression, it has never thought about going over to its co-religionists and for long has not been fanatic." 5

An examination of the Crimean Tatars' status during the Crimean War (and earlier Russo-Turkish wars) favors the latter viewpoint and, in many ways, explains the unprecedented mass migrations of Crimean Tatars to the Ottoman Empire during the mid-nineteenth century. Most contemporary accounts indicate that the Crimean Tatars were victimized during the Crimean War and this experience destabilized this community and left it prone to calls for migration from community religious leaders.

\section{The status of the Crimean Tatars during the early Russo-Turkish wars}

It is generally agreed that the roots of the mass nineteenth-century migration of the Crimean Tatars to the Ottoman Empire lay in this minority's treatment during the Crimean War of 1853-1856. While there were many factors operating in the nineteenth-century Russian province of the Tauride that would have impelled the Crimean Tatar community of this era to abandon its homeland for the Ottoman Empire (in particular mass land confiscations by Russian landowners known as pomeshchiki), the pressure to emigrate was dramatically increased in time of war. Eighteenth- and nineteenth-century Russian authorities were all too aware of the Crimean Muslims' continuing identification with the Ottomans during the Russo-

2. Evgenii Markov, Ocherki Kryma (Simferopol': Tavria, 1995): 122.

3. G. I. Levitskii, “Pereselenie tatar iz Kryma v Turtsiiu,” Vestnik Evropy, 5 (1882): 125.

4. E. I. Totleben, “O vyselenii tatar iz Kryma v 1860 godu,” Russkaia starina (June 1893): 534.

5. A. Herzen, “Gonenie na krymskikh tatar,” Kolokol, 117 (Dec. 22, 1861): 973. 
Turkish wars of 1787-1792, 1806-1812, 1828-1829, 1853-1856 and 1877-1878 and considered this Islamic community to be a potential fifth column in time of war. There were of course grounds for distrusting the Crimean Tatars' historic, cultural, ethnic and religious links with the Ottoman Empire. On many levels the Crimea's Muslim community certainly did consider itself to belong to a religiously-defined "imagined community" (the umma, the ecumenical community of Muslims) that included the Ottoman Muslims.

Russian military strategists in particular feared the presence of this unreliable Muslim community in the Crimean peninsula which was seen as a vital fortress guarding Russia's southern flank against the Ottomans. In order to prevent any collaboration between the Ottoman fleet and the Crimean Muslims, the Russian government often took the preemptive measure of removing Tatar villagers six or more miles from the southern shore during time of war with the Ottoman Empire. During the 1787-1792 Russo-Ottoman war, for example, Andrei Markevich writes:

\begin{abstract}
"When sultan Selim [sic] declared war against Russia, it was again necessary to secure the Crimea from the landings of the Turks and to ascertain the mood of the Tatars. The local authorities decided to use the same objectives and measures utilized in the second Turkish War by Catherine and, first of all, to resettle the Tatars from the south shore; and the mufti (chief Islamic jurist) and mirzas (coopted Tatar aristocracy) were in agreement with them. The whole operation was carried out, according to the wishes of the Tatars, without the interference of the police. All the Tatars of the south shore were resettled, except the inhabitants of Tuak who tearfully swore an oath of allegiance to Russia and several other villages." 6
\end{abstract}

During the 1806-1812 Russo-Turkish war, Russian authorities again took preventive measures against the Crimea's Muslim population by expelling them from many villages on the southern shore and confiscated their vessels. ${ }^{7}$ Partly in response to these governmental actions there was a limited uprising in Bahçesaray (the former capital of the Crimean khans and a Tatar enclave in the nineteenth century) in 1808 , but this was of a local nature and did not spread beyond the immediate vicinity. Although a Turkish fleet appeared off the coast of the Crimea during this war, the Crimean Tatars remained calm at this time. ${ }^{8}$

Regardless, the Crimean Tatars' position in Russia had deteriorated during the Russo-Turkish war of 1806-1812 and, during this conflict, as many as 3,200 Muslims emigrated from the Crimean peninsula proper to the Ottoman Empire. ${ }^{9}$ The most notable movement to the Ottoman Empire on this occasion did not occur among the Tat and Yaliboyu Tatar population of the southern Crimea

6. Arsenii Markevich, "Pereseleniia krymskikh tatar v Turtsiiu v sviazi s dvizheniem naseleniia v Krymu,” Izvestiia Akademii Nauk SSSR, series 7, no. 4 (1928): 390.

7. David Lynch, The conquest, settlement and initial development of New Russia (New Haven: Yale Univesity Press, 1969): 92.

8. A. Markevich, art. cit.: 391 .

9. V. Vozgirin. Istoricheskie sud'by krymskikh tatar(Moscow: Mysl', 1992): 309. 
(sub-ethnic divisions among the Crimean Tatars who lived in the mountains and on the southern coast of the Crimea) but among the Nogais (the nomadic Kipchakspeaking sub-ethnic Tatar group who lived on the Crimean steppe and adjacent steppe lands in the Ukraine). With the signing of the Treaty of Bucharest in 1812, the Russian Empire expanded its borders at the Ottoman Empire's expense and annexed the Buçak (Bessarabia).

For hundreds of years this steppe area, in what is now southern Moldavia, had been the homeland of the Buçak Nogai Horde. Prior to 1812, the Buçak had in fact served as a refuge for Nogai Tatar nomads seeking to evade Russia's policies of forced settlement and this element could not be reconciled to Russian rule. With Russia's expansion into this last corner of the European steppe, the Buçak and the adjoining Yedisan Horde (which dwelled in the territory to the east of the Buçak) abandoned their homelands and withdrew in a south-westerly direction along the Black Sea towards the nearest territory of the Ottoman sultan. The Yedisan and Buçak Nogais' migration took them across the Danube River and into the Ottomancontrolled plain of Dobruca (coastal Romania) where they were received by the Ottomans as muhacirs (religious immigrants).

Approximately 7,000 Nogais are estimated to have vacated the steppe at this time and a considerable area was opened up for Russian, Ukrainian and Moldavian settlement. ${ }^{10}$ By the end of 1812 a historian focusing on the Buçak has claimed that "there were practically no Tatars left in the region." 11 As to the plains of the Yedisan Horde located to the northwest of the Crimean peninsula, a nineteenthcentury source claimed "Christian and Jewish settlers had taken the place of the Tatars belonging to the Yedisan Horde, who inhabited this steppe at the commencement of the last half of the eighteenth century." 12

The tsarist empire faced its gravest threat during Napoleon's subsequent invasion of Russia in 1812 and on this occasion, far from betraying Russia, a Crimean Tatar volunteer cavalry squadron served with distinction in the decisive battle of Borodino. The Tatar light cavalry, led by Ahmet Beg Kungarovich and a Colonel Begildeev, garnered many medals in the battle of Borodino and proved that there were segments of Crimean Tatar society prepared to give their lives for the tsar..$^{13}$ According to another account, "The general quietness of the Tatars and the participation in the war of the Tatar cavalry should have returned the Crimean Tatars to the confidence of the government; a confidence which vacillated with unfavorable rumors, especially concerning the inhabitants of mountainous parts of the Crimea." 14

10. A. Markevich, art. cit.: 392.

11. Andrei Popovich, The political status of Bessarabia (Washington, D.C. : School of Foreign Service, 1931): 25.

12. Charles Koch, The Crimea from Kertch to Perekop (London: Routledge, 1855): 128.

13. P. G. Landau, Islam v istorii Rossii (Moscow: Vostochnaia Literatura, 1995): 90.

14. Ibid.: 391 . 
This was not, however, to be the case and, in spite of the Crimean Tatars' valor during the French invasion, tsarist officials continued to distrust the Crimean Muslims. Their fears appear, however, to have been exaggerated and it has been pointed out that in 1783 the Crimea's military aristocracy had, for the most part, migrated to Ottoman lands in the neighboring territories in the Caucasus (via the Taman peninsula) to the Buçak or across the Black Sea to Anatolia at the time of the Crimean khanate's annexation. ${ }^{15}$ Russian historian Valerii Vozgirin claims that the humbled Tatar population that remained in the Crimean peninsula was disarmed by Russian officials in 1784 and the passive Crimean Muslim peasantry's military potential was certainly insignificant by the nineteenth century. 16

The Tatar population of the Crimea was again the target of preemptive administrative displacement from coastal villages during the short Russo-Ottoman war of 1828-1829. This suspect community appears, however, to have been passive throughout the course of the war. ${ }^{17}$ In spite of their loyal behavior during this war, Russian officials took the cautionary measure of establishing a defensive cordon of Azov Cossack units in a broad area stretching from the Crimean peninsula to the Buçak. These units appear to have taken advantage of this opportunity to pillage Tatar villages in the area. ${ }^{18}$

Despite pressure of this nature, there was no large-scale migration to the Ottoman Empire during the second Russian-Ottoman conflict of the nineteenth century. The situation in the Crimea in fact remained outwardly tranquil over the next quarter of a century, but this surface calm hid the growing dissatisfaction that the Crimean Tatars, who continued to suffer from land confiscations, began to feel in the Russian Empire. As storm clouds appeared in the Holy Land as a result of tsar Nicholas' claims to the Ottoman-controlled holy sites of Jerusalem, the Tauride province's Crimean Tatar population (i.e. Tat, Yaliboyu and Nogai sub-ethnies) would have had little reason to feel secure in their Russian homeland.

\section{The commencement of the Crimean War}

In 1853 the historic rivalry between the Ottoman and Russian Empires again flared up and led to open warfare and, in predictable fashion, the Russian army invaded the Ottoman provinces of Rumelia (i.e. Rum-eli, "the Land of Rome," the truncated European sections of the Ottoman Empire). In the first year of the war the Russian army spread fire and sword throughout many Muslim villages of the region of the Ottoman provinces that would later form the independent states of Romania and Bulgaria. This destruction soon spread to the coastal plains of Dobruca inhabited by

15. Alan Fisher, "Emigration of Muslims from the Russian Empire in the years after the Crimean War,” Jahrbücher für Geschichte Osteuropas, 35, 3 (1987): 358.

16. V. Vozgirin, op. cit.: 297.

17. A. Markevich, art. cit.: 392.

18. A. Fisher, art. cit.: 357. 
the Crimean Tatars (predominantly Nogais) who had fled the inexorable Russian advance into their steppe homelands to the north.

Fearing an increase in Russian power in the strategic Bosphorus straits at the expense of the enfeebled Ottoman Empire, France, Britain and Sardinia joined the sultan in expelling the Russians from the Ottomans' Balkan provinces in 1854. The Allies' combined army quickly went on the offensive and decided upon an attack on one of Russia's most vulnerable spots, the Crimean peninsula. Thus was born the Crimean War which has been studied endlessly, in part, because of the unprecedented toll in lives it took on tens of thousands of soldiers on both sides. While there has been considerable research on the role that disease, poor sanitary conditions and the increasingly effective modern weaponry of the mid-nineteenth century took on the combatant nations, little attention has been devoted to the impact this war had on the indigenous population inhabiting the theater of conflict. That this war was in fact to have dire results for the Crimean Tatar peasants who became caught up in this, the first "hot conflict" of the Russian and British struggle for power in Eurasia known as the Great Game, was to be seen almost from the start of the Crimean invasion.

The allied operation in the Crimea began with an amphibious landing in the broad Kalamita Bay off the shore of Evpatoriia (still known to the Crimean Muslims by its old Tatar name, Gozleve) on the western coast of the Crimean peninsula. Here the British and French soldiers came into contact for the first time with the remnant of the once numerous Tatar inhabitants of the northern coasts of the Black Sea. The following narrative of the initial meeting between the English and the indigenous Muslim population is typical of the wary, but often cordial, greeting the Allies appear to have found among the Crimean Tatars whose villages presented a backdrop for some of the worst fighting in nineteenth-century Europe:

"When the people of the neighboring district came to see the strength of the armies descending upon their coast, the head men of the villages began to present themselves at the quarters of the Allies. The first of these deputations was received by Lord Raglan in the open air. The men were going up to headquarters when they passed near a group of officers on foot in blue frock coats, and they learned that the one whose maimed arm spoke of other wars was the English General. They approached him respectfully, but without submissiveness of an abject kind. Neither in manner, dress, appearance, nor language, would these men seem very strange to a traveler acquainted with Constantinople or any of the other cities of the Levant. They wore the pelisse or long robe, and, although their head-gear was black lamb-skin, it was much of the same shape as the Turkish fez. They spoke with truthfulness and dignity, allowing it to appear that the invasion was not distasteful to them, but abstaining from all affection of enthusiastic sympathy. They seemed to understand war and its exigencies; for they asked the interpreters to say that such of their possessions as might be wanted by the English army were at Lord Raglan's disposal."19

19. Alexander Kinglake, The invasion of the Crimea. Its origin and an account of its progress (New York: Harper and Brothers, 1874), 1: 422-423. 
As the Allies commenced their partial occupation of the south-western Crimea and the long siege of the Russian naval bastion of Sevastopol, there were many such contacts between the invaders and the Tatars who were densely settled in this region. For the most part, the Muslim peasants, having had considerable experience with armies in the past, greeted the invaders with reserved caution.

In the Evpatoriia and Yalta vicinity, however, there were instances of Crimean Tatar peasants taking advantage of the invasion to burn the estates of some of the most oppressive pomeshchiki. ${ }^{20}$ In the Allied amphibious invasion of the port of Kerch on the far eastern coast of the Crimea, local Tatars from the countryside (and Russians) also partook in the general plundering of this town which resulted from a breakdown of discipline among the allied landing force. One can also speculate that the Crimean Tatars of the Baidar valley (south-western Crimean mountains) fraternized with the Ottoman portion of the Allied army stationed in this Tatarinhabited valley during the siege of nearby Sevastopol. These examples of disloyalty led many in St. Petersburg to look upon the entire Crimean Muslim population as real or potential traitors to the Russian Empire at the height of war.

This attitude was of course not new in Russian administrative circles. It is interesting to note that, in the days just before the invasion, Prince Menshikov, the Russian general in charge of the Crimean front, had actually proposed the expulsion of the entire Crimean Tatar population to the mainland as a precautionary measure. A second tsarist official, a Minister Koppen, went even further and called for the forced transfer of the Crimea's entire Tatar population to Semipalatinsk (Eastern Siberia). ${ }^{21}$ As such attitudes spread in the highest echelons of government, the idea that the Crimean Tatars were a dispensable population whose expulsion was a natural proposition became widespread in the Russian administration. The speed of the Allied invasion and the logistical efforts that would have been diverted from war preparations for an operation of this scale, however, prevented further discussion on the implementation of this drastic solution to the Crimean Tatar "problem". ${ }^{22}$ It remained for Joseph Stalin to implement Koppen's solution during the closing days of World War II.

\section{Cossack wartime depredations in the Evpatoriia district}

While this immediate threat to the Crimean Tatars had been removed, they faced a new danger in the form of Cossack sotiny (squadrons) sent to patrol the peninsula's Muslim villages during the siege of Sevastopol. It should be mentioned that the Cossacks, who earned a reputation for their pogroms against Russian Jews of the Pale in the nineteenth century, also had a deep-seated antipathy towards their

20. A. Markevich, art. cit.: 393 .

21. Ibid.: 394 .

22. B. M. Vol'fson, "Emigratsiia krymskikh tatar v 1860 g.," Istoricheskie zapiski, 9 (1940): 186-197, here 187. 
historic enemies, the Muslims. For centuries Cossacks had guarded the tsar's frontiers against the inroads of Muslim peoples, such as the Turks, Tatars, Chechens, Kazakhs and Circassians, and warfare against Muslims during Russia's expansion in the Caucasus was ingrained in this frontier people's culture. It is not surprising then that the Cossack units assigned to guard the approaches to the allied-occupied Evpatoriia district took advantage of this opportunity to indulge their natural proclivity to plunder their traditional enemy, the Muslims.

General Totleben, the Russian general whose name became widely known throughout the Empire and the West for his heroic leadership in the defense of Sevastopol, seems to have looked upon the attacks of the Cossack military units (headed by an official identified only as Maksimov) on the Crimea's civilian Tatar population with some distaste. In his article on the Crimean Tatar emigration, this uniquely qualified, eyewitness source wrote:

"Maksimov, with the Cossacks began to punish and rob the villages of the Tatars and forcefully outraged women, in the village of Tshei they flogged to death 7 men and announced that, with the arrival of the Russian army, all Tatars would be killed. At that time the proclamation of Marshall St. Arno [St. Arnaud, the French commander] promising complete protection was read and 20,000 Tatars of the Evpatoriia district went over to the allies." 23

Other contemporary Russian sources support Totleben's account of events in the Evpatoriia district during the Crimean invasion. In his account, G. Levitskii claimed:

"During the course of the recent war, Cossack patrols moving through the district arbitrarily seized unfortunate Tatars under the pretext that they intended to go over to the enemy and forced them to pay ransom and, if they refused, they were handed over to the command as deserters and traitors [...]. Therefore at the present there are many Tatars in the provinces of Orlovsk, Kursk, Poltava, Ekaterina and Kherson who are entirely innocent."24

During their attacks on the Tatar villages of the Evpatoriia district, the Don and Ural Cossacks also drove off the local Nogai Tatars' cattle and raided their yamas (underground grain storage bins). ${ }^{25}$ In addition, Cossack patrols arrested and deported any Tatars who left their village to collect water. ${ }^{26}$ According to another account "If a group of 20 Tatars gathered they were fired upon. This was also a betrayal. The Cossacks so loved this idea that they looked upon the entire Crimea as upon traitors. Under this mandate, they drove away herds of sheep, burnt down whole villages and even the farms of pomeshchiki ..."27

23. E. I. Totleben, art. cit.: 332.

24. G. I. Levitskii, art. cit.: 605.

25. V. Vozgirin, op. cit.: 325.

26. G. I. Levitskii, art. cit.: 605.

27. E. Markov, op. cit.: 115 . 
In their defense, some of the Cossacks' tactics in the Evpatoriia district can be attributed to their traditional scorched earth policies. Many of the villages in this region may have been destroyed simply to prevent the Allies from obtaining supplies from the local villagers. On more than one occasion Allied patrols arrived at a village to find that it was in the process of being burnt by Cossack units that shadowed their movements. A British source mentions this phenomenon in his work and writes of his squadron's passage through the Crimean countryside "The sky was illuminated as usual with the light of burning villages, which the Cossacks had fired up the country." 28

As a result of these depredations, thousands of Tatars from the predominantly Nogai-inhabited Evpatoriia district fled to the Allied occupied city of Evpatoriia seeking sanctuary. A contemporary Russian source describes this panicked flight to Evpatoriia to escape the Cossack marauders and claims "Fearing most of all the pursuit of the Cossacks, whole Tatar villages moved to Evpatoriia and its environs and died there in droves from starvation and lack of housing." 29

As many as 20,000 Crimean Tatar refugees sought asylum with the departing allies and were evacuated on allied ships at the end of the Crimean campaign. Mark Pinson claims that an additional 10,000 to 20,000 Tatars may have emigrated to the Ottoman Empire during the war, making this the largest departure of Crimean Tatars from the Tauride district since a mass migration that had taken place in 1792. ${ }^{30}$ Markevich points out that the majority of Crimean Tatars who left the Crimea during the war came from Evpatoriia, the Baidar Valley (headquarters for the Ottoman army headed by Omar Pasha during the war) and Balaklava (a harbor on the south-western tip of the Crimea which saw some of the fiercest fighting of the campaign). ${ }^{31}$ At war's end this abandonment of Russia by the Crimean Tatars was seen as a clear manifestation of betrayal by the military authorities in Sevastopol.

\section{The question of the Crimean Tatars' wartime betrayal}

In the devastated military port of Sevastopol itself there was a growing distrust of the Muslim peasants of the surrounding countryside and in many ways the local Tatars reciprocated this feeling. Sevastopol had, from the beginning of Russian rule in the Crimea, been an alien Russian enclave in the Muslim Crimea and was perhaps that part of the Crimea that was most thoroughly Russian in an ethnic, political, cultural and administrative sense. With the collapse of the Soviet Union in

28. Nicholas Woods, The past campaign. A sketch of the war in the East (London: Longman, Brown and Green, 1855): 314.

29. V. Vozgirin, op. cit.: 325.

30. Mark Pinson, "Russian policy and the emigration of the Crimean Tatars to the Ottoman Empire 1854-1862," Guney-Dogu Avrupa Arastamalari Dergisi, 1 (1972): 44.

31. A. Markevich, art. cit.: 395. 
1991 and the declaration of an independent Ukraine (which has inherited control of the Crimea), Sevastopol has again become a purely Russian foothold and a bastion of Russian nationalism (and Soviet-era conservatism) in a foreign land. Declared off-limits during the Soviet period, this strategic base was finally opened to outsiders in 1996 and the author visited this site which has much of the patriotic symbolism for the Russians that the Alamo or Pearl Harbor has for Americans.

Today in Sevastopol there are many memorials to both the heroic defense of Sevastopol during Crimean War and to the bloody Nazi siege of the fortified harbor in World War II. While statues of Lenin have been toppled throughout the former USSR and many outward symbols of Communism destroyed in the former Soviet lands, these symbols are still prominent in Sevastopol and visitors to this military base today may feel as if they are entering a Soviet-era time warp. The largest statue of Lenin this author has witnessed in the former Soviet Union still dominates the port; all signs are in Russian (even though the port of Sevastopol is nominally a part of the Ukraine); red Soviet or the tri-color Russian flags fly on most buildings and on the frigates in the harbor; and nostalgia for the old days of order personified by Lenin and Stalin is commonplace here. The author arrived in Sevastopol in November 1997 in time to witness a Soviet-era parade on Sevastopol's main street celebrating the founding of the Soviet Union. Russian naval cadets dressed in uniforms still bearing the hammer and sickle led the parade and marchers in the column appeared to be of all ages, although the elderly predominated.

As my Crimean Tatar hosts witnessed this celebration of the state which had done so much to destroy their nation they became visibly agitated when marchers began singing the Soviet national anthem and waving banners emblazoned with the face of Josef Stalin, the man who had personally given the order for their people's deportation during World War II. While the returning Crimean Tatars have imagined a homeland described to them in the stories of their parents and grandparents, Sevastopol, the "Pride of Russia" is certainly not what these returnees envisioned. Newspapers printed by the city's conservative military press, such as Flag rodiny, are replete with anti-Tatar agitation and few Crimean Tatars have actually settled in this military zone.

Much of the predominantly Russian population of Sevastopol still remembers the Crimean Tatars as traitors to Russia and the Soviet Union (which are synonymous in many Crimean Russians' minds now) and they are largely unwelcome and distrusted here. Although the Crimean Tatars still stubbornly call Sevastopol (a city of almost a quarter of a million people) by the name of an insignificant Tatar hamlet that existed here over two hundred years ago, Ak Yar (White Precipice), this enclave is, for all intents and purposes, a part of the Russian rodina (Russian for homeland) not the Crimean Tatar vatan (Tatar for homeland). Despite the fact that it is, along with Simferopol, the largest urban area in the Crimea few Crimean Tatars have felt the lure of this Russian city.

As members of a suspect "nation of traitors," my Crimean Tatar hosts were visibly relieved to leave Russian Sevastopol and this feeling may have been shared by nineteenth-century Crimean Tatars throughout the entire Crimea after the 
Crimean War. In addition to the usual land confiscations, after the war the Crimean Muslims began to experience outward manifestations of discrimination and distrust on the part on the Russian authorities. Like the Crimean Tatars of today, the postCrimean War era Tatars were considered a suspect people in their own homeland and this stigma certainly weighed heavily on this proud Muslim people. In addition to living under blanket accusations of treason, many Tatar villages had suffered from Cossack plundering, military requisitioning and displacement, and had subsequently failed to receive financial assistance or recompense for their wartime losses from distrustful government officials.

At the conclusion of the war it became apparent that the Nogai Tatars of the Evpatoriia district had suffered the most during the campaign but all Crimean Tatar sub-ethnies were adversely affected by the events surrounding the war. Although there were no accusations of collaboration leveled against the Tatars of the coast, the Yaliboyu Tatars, for example, Alan Fisher claims:

"When many Crimean Tatar peasants were removed from the coast during the Crimean War, pomeshchiki took advantage of the opportunity afforded. They expended great effort to prevent the Tatars' return. Imposing higher taxes and duties on the returning Tatars, seizing water supplies, they forced peasants to remain inland or, as a last resort, to emigrate to the Ottoman Empire."’32

Powerful landowners throughout the Crimea were quick to turn the accusations of treason against the Crimean Tatars to their profit by using this blanket accusation to force "suspect" Muslim peasants off their lands. The issue of the Crimean Tatars' betrayal of Russia during the Crimean War also has tremendous significance for this people's descendants who have returned to a largely Russian Crimea in the post-Soviet context. These Crimean Tatar settlers still live with the stigma of having betrayed Russia and the Soviet Union during two of its most crucial military engagements. An analysis of this issue reveals that the depth of the Crimean Tatars' collusion with the Allies during the Crimean War has, like their accusations of betrayal during World War II, been greatly exaggerated by their detractors.

Extended research into this issue has led the author to the conclusion that there is no reference in English or French accounts of the Crimean War to the Crimean Tatars as allies or an indigenous source of military or logistical assistance during the campaign of 1854-1856. Even if this had been the case, this largely passive, unarmed peasant population could certainly not have affected the outcome of such decisive military encounters as the battles of the Alma, Balaklava or the siege of Sevastopol. The majority of rumors of the Tatars' betrayal seem to have in fact been spread after the war by land speculators seeking to take advantage of the distrust in military circles to expel the Muslim peasantry from their prized lands. According to contemporary sources, after the war, Russian and Greek land speculators also

32. Alan Fisher, "Social and legal aspects of Russian-Muslim relations in the nineteenth century. The case of the Crimean Tatars," in Abram Ascher et al., eds, Mutual effects of the Islamic and Judeo-Christian worlds. The European pattern (New York, 1979): 82. 
began circulating rumors among the frightened Crimean Muslim peasantry claiming that the Russian government intended to expel the entire Crimea's Tatar population to the Orenburg district of Siberia for wartime treachery. ${ }^{33}$ Their intent was to frighten the passive Tatar peasantry into emigrating and freeing up their lands for purchase at base prices. Such rumors certainly destabilized this warstricken community in the years after the Crimean War and also led to a debate in Russian circles concerning the level of the Crimean Tatars' traitorous activities during the war.

Discussion of the Crimean Tatars' wartime treachery continued into the Soviet period and, in his work, the most vocal disseminator of post-deportation antiCrimean Tatar propaganda, P. N. Nadinskii writes:

"After the landing of enemy troops in Evpatoriia, the Crimean Tatars in large numbers went over to the enemy. From among the Tatar volunteers in Evpatoriia under the command of the Anglo-French and Turkish officers, special brigades of askers (soldiers) were formed. The total number of Tatar special brigades that were formed was 10,000.”34

Contemporary Russian historian V. E. Vozgirin treats Nadinskii's 1950s anti-Tatar account of the Crimean Tatars' betrayal with scorn in his recent work and points out that the myth of the Crimean Tatar army was based on the short-lived existence of a largely ineffectual 800-man Tatar village militia organized to defend Muslim villages from Allied marauders. ${ }^{35}$ It does in fact seem highly improbable that the Crimean Tatar refugee population of Evpatoriia, which at most numbered 20,000 (including women, children and the elderly), could field an army of 10,000 soldiers. More importantly, Western sources would have certainly mentioned the existence of an anti-Russian Tatar military formation of this size operating in the Crimean theater. K. Kogonashvili points out that two Tatar divisions actually partook in the defense of Sevastopol in 1854-1855 and this contribution has gone completely unnoticed in many anti-Tatar sources. ${ }^{36}$

The Tatar collusion with the Allied invaders in Evpatoriia appears to have actually been of a rather limited nature. During the Crimean campaign Pinson claims that some of the Tatar refugees in Evpatoriia assisted the Allies in constructing defenses for the city during the English and French occupation of the port. ${ }^{37}$ Few could deny that this refugee element had come to tie its fate to that of the Allies, and not the tsarist government which was represented in the Crimea by plundering Cossack squadrons. Having provided perhaps the most in-depth analysis of the reported incidents of Crimean Tatar betrayal during the war a

33. A. Herzen, art. cit.: 973 .

34. P. N. Nadinskii, op. cit.: 140.

35. V. Vozgirin, op. cit.: 328 .

36. K. Kogonashvili, Kratkii slovar' istorii Kryma (Simferopol': Biznes-Inform, 1995): 151.

37. M. Pinson, art. cit.: 44 
Russian witness declared "All these accusations were insufficient to censure an entire people." 38

In the aftermath of the Crimean War there was nevertheless a feeling among government circles that the Crimean Tatars had somehow played a role in the Russian defeat in the conflict. It is interesting to note, however, that Russians actually living in the Crimea after the war were of a different mind. A nineteenthcentury visitor, for example, provides the following anecdote which relates his discussion with Russians in the Crimea after the war:

"Here I did not meet one long time inhabitant who did not scorn with all his heart the mean censure of the Tatars which resulted in such a disaster for the entire region. [...] Again one may ask 'Is this really a voluntary betrayal of the government?' Even in the very places of the landing, the Tatars remained quiet and faithful. One pomeshchik known to me, on the day of the landing, arrived at his estate located not far from Burliuka and ordered the hay and grain to be burned upon the first approach of the enemy. The Tatars placed their hands on their hearts and promised to execute the order. The enemy arrived and the hay was burnt. There are your traitors! However, even if the Tatars finally really did engage in betrayal, they should be absolved. One would need to be a true follower of Allah and a fatalist to quietly endure that which was done to this poor people during the campaign." 39

For the most part, the unarmed Crimean Tatar peasants do appear to have been little more than spectators to the massive battles fought between modern armies that surged over the south-western sections of their homeland and the vast majority followed the Crimean Mufti's edict ordering them to "be faithful to the tsar and homeland." 40 Regardless of the facts, rumors of the Crimean Tatars' "mass betrayal" reached the ears of the tsar himself. As news reached St. Petersburg that some fearful Crimean Tatar peasants had begun to emigrate in the years after the war, tsar Alexander II himself sent word to the Crimea stating "It is not appropriate to oppose the overt or covert exodus of the Tatars. On the contrary, this voluntary emigration should be considered as a beneficial action calculated to free the territory from this unwanted population." 41 When news of the Ak Padishah's ("White Tsar" as he was known to the Crimean peasants) declaration reached the Tatar villages of the Crimea, Totleben claims "The Tatars accepted this as a forced measure of eviction, concluding that they had forever lost the favor of the tsar." 42

38. G. I. Levitskii, art. cit.: 604.

39. E. Markov, op. cit.: 112, 114.

40. V. Vozgirin, op. cit.: 323.

41. A. Markevich, art. cit.: 395.

42. E. I. Totleben, art. cit.: 538 . 


\title{
The Russian conquest of Circassia and the start of the Muslim migrations of 1860
}

As the word of the tsar's attitude towards them spread among the Crimea's Tatar villages, news also began to reach the Crimea of events unfolding in the nearby north Caucasian flank in the summer of 1859. After decades of determined struggle, the redoubtable Sheikh Shamil's force of Avar, Chechen, Kumyk and Ingush mountain gazis (anti-Russian guerrillas) had at last succumbed to the might of imperial Russia. The victorious Russians subsequently began mopping up operations in the lands of the last independent Caucasian people, the Circassians. One after another the terraced mountain villages of the Circassians (which closely resembled those of the Tat and Yaliboyu Tatars in the southern Crimea) fell to the Russians who used scorched earth tactics to crush the fiercely independent Muslim highlanders. The following account of the conquest of Circassia provided by a Russian who served in the conquering army demonstrates the viciousness of the campaign in which no quarter was asked or given:

\begin{abstract}
"The war proceeded with inexorable and merciless severity. We pushed ahead one step at a time, but remorselessly, clearing every patch of land where a soldier set foot on mountaineers, down to the last man. The mountain auls were burned by the hundred. The snow had only just melted away, but it was before the trees had become clothed in their greenery (in February and March); the crops were eaten by the horses or even trampled down. If we managed to catch the inhabitants of the auls unawares they were immediately led away under military escort to the shores of the Black Sea and then sent to Turkey. How many times did it happen that in the huts which had been hurriedly abandoned upon our approach we found warm gruel with a spoon in it on the table, clothing which was being repaired and with the needle still in it, and various children's toys which looked as though they had been spread out on the floor next to a child. Sometimes - to the credit of our soldiers - very seldom, bestial atrocities were committed." 43
\end{abstract}

In the process of conquering the Circassian lands, the Russian army engaged in demographic warfare that would today be considered mass ethnic cleansing. Well over a million Circassians (the largest ethnic group living on the northern Caucasian flank) were forced from their Caucasian homelands between 1859 and 1864 (some estimates are as high as 1.5 million) and the mortality rate among these emigrants reached unprecedented heights. It has been estimated that hundreds of thousands of this number died due to disease, starvation or drowning during the migration and resettlement. ${ }^{44}$ Ottoman statistics from 1867 record only

43. Barsabi Baytugan, “The North Caucasus,”. Studies on the Soviet Union (New Series), XI, 1 (1971): 1-38, here 10 .

44. Kemal Karpat, "Ottoman immigration policies and settlement in Palestine," in Ibrahim Abu-Lughod and Baha Abu-Laban, eds, Settler regimes in Africa and the Arab world. (Wilmette, IL: Medina University Press International, 1974): 7-72. 
1,008,000 Circassians in the Ottoman Empire and the Circassian migration was, by all accounts, a humanitarian disaster.

While this mass departure from the Caucasus by the Muslim highlanders can safely be described as a forced migration, there was also an underlying religious pull in the Circassian Muslims' desire to emigrate to the "white soil" of the Ottoman Empire. One Westerner observed "To all advice that they should remain in the Kuban, they answered 'We want to live and die among our fellow Moslems. Our desire is to rest our bones in holy soil'.,"45

To the Crimean Muslims who felt increasingly insecure in their own homeland after hearing the tsar's pronouncement, the fall of the Muslim North Caucasus and expulsion of the legendary Circassian highlanders signaled the end of Islam in the northern Black Sea littoral. Rumors began to spread through the Crimean Tatar villages at this time that the Russian government intended to forcefully convert the Crimea's Muslim population or expel them to Siberia. ${ }^{46}$ A wave of panic also spread among other Muslim peoples and many indigenous Caucasian groups began to migrate to the Ottoman Empire in a vast migration transfer that presaged the exchange of populations between Greece and Turkey following World War I. In addition to the Circassians, as many as 40,000 Chechens and tens of thousands of Ubykhs left for the Ottoman Empire in 1860. The Muslim portion of the Abkhazian population that lived in coastal Georgia (approximately 110,000) left their homeland at this time leaving a small, largely Orthodox Abkhazian population which would plague the Georgian government in the aftermath of the Soviet collapse (and would come to be erroneously portrayed as Muslims in the West). ${ }^{47}$ The Laz of the south-western Caucasus also began to migrate to the lands of the sultan as the Russians rounded out their conquests in the northern Caucasus. ${ }^{48}$

\section{The steppe Nogais and Russian rule up to 1860}

The migration movement soon spread to the Nogai Tatars of the Kuban plains of the northern Caucasus who appear to have been quite susceptible to calls for the abandonment of the Russian Empire. The Kuban Nogais had suffered from Russian and Cossack encroachments on their grazing grounds since the 1783 annexation of the Crimean khanate and many of this people had, by the mid-nineteenth century, grown dissatisfied with Russian rule. From the beginning of the tsarist conquest of the Kuban, Russian administrators had distrusted the presence of this nomadic

45. Seteney Shami, Ethnicity and leadership: The Circassians in Jordan (University of California doctoral dissertation, 1989): 41.

46. G. I. Levitskii, art. cit.: 626.

47. T. Abkazian, "Literature on Abkhazia and the Abkhazian-Abazian," Caucasian Review, 16, 3 (1968): 217-222.

48. Peter Alford Andrews, Ethnic groups in the Republic of Turkey (Wiesbaden: Ludwig Reichert Verlag, 1989): 172. 
horde on their unstable borders with the Ottoman-dominated Circassian coast. The Russian military had soon come to the conclusion that this people's removal was essential for the stabilization of this turbulent frontier zone. When, in 1783, the Nogai biys (tribal leaders) discovered that the Russian government intended to transfer the Kuban Horde from its traditional pastures to lands south of the Urals recently vacated by the Kalmyk Mongols (most of whom migrated to China in 1771), they rose in revolt against their new masters. The Russian southern army under General Suvorov had, it would seem, anticipated the Nogais' actions. John Baddley describes the results of the Kuban Nogais' doomed uprising in his classic history of the Russian conquest of the Caucasus:

"When the infuriated Nogais proceeded to attack the nearest Russian detachments, regiment after regiment closed in upon them, and in a short time all was over. Driven into boggy ground, and seeing no possibility of escape, the miserable nomads in mad excess of despair destroyed their valuables, slaughtered their women, and threw their little children into the neighboring stream."49

In the ensuing slaughter Ia. Smirnova claims as many as 7,000 Nogais were killed and thousands of Nogais fled to neighboring Circassia. ${ }^{50}$ By 1791 many of those Nogais that had fled to Circassia, however, returned to Russia and were settled by the Russian government to the north-east of the Crimean peninsula between the Azov Sea and the Molochnaia River. ${ }^{51}$ Subsequently a remnant of several thousand Nogai families were permitted to remain in the Kuban steppe in the Eisk (the plain to the north-west of the Caucasus) vicinity while the remnants of the Yediçkul, Djambulaq and Yedisan Hordes were also settled in the steppe districts of the Tauride province. ${ }^{52}$ In addition, a large number of Nogais were settled in the Stavropol region adjacent to the Kuban.

Russian governmental policies towards the Nogais of the Kuban and those who inhabited the steppes to the north of the Crimea in the Tauride province between the Azov and Molochnaia River soon focused on settlement of these traditionally unsettled nomads. According to Smirnova "From the first day of their transfer to the Crimea all the political powers dealing with them were directed towards their settlement." 53

In the early nineteenth century, the Nogais of the Tauride province were governed by a Count Maison who patiently endeavored to settle these wandering

49. John Baddley, The Russian conquest of the Caucasus (London: Longman, Green and co., 1908): 44.

50. Ia. S. Smirnova et al., Nogaitsy: Istoriko-etnograficheskii ocherk (Cherkesk: Stavropol'skoe Knizhnoe Izdatel'stvo, 1988): 37.

51. Ebenezer Henderson, Biblical researches and travels in Russia including a tour of the Crimea (London: James Nisbet, 1826): 379.

52. Ia. S. Smirnova et al., op. cit.: 37 .

53. Ibid. 
nomads. Maison drew circles around the Nogais' encampments and forbade them to transfer their yurts (portable tents) beyond these demarcated areas. After this step had been completed, a contemporary source writes:

"There now remained but one step to finish the work which had been so far unsuccessful. In 1812, Count Maison, who, though a solitary Frenchman, in the midst of ill-satisfied hordes of the wildest people in Europe, seems, by his address, to have secured that every tent which remained should be publicly paid for and destroyed." 54

These policies were certainly unpopular among the Nogai herders who traditionally resented the intrusion of any authority. The increasing encroachment by the Russian bureaucracy into the Nogais' traditionally unrestricted way of life had many parallels with the tsarist government's infringement on the neighboring Mongol Kalmyk nomads' traditional patterns. The Buddhist Kalmyks (the true Mongols of the steppes, who lived to the east of the Kuban for two centuries) chafed under the government's increasing interference in their lands and, in 1771, the vast majority of the Kalmyk nomads emigrated across the Kazakh plains to Manchu China to escape Russian rule.

The Tauride Nogais' cause for grievance grew during the Crimean War as the Russian government made considerable logistic demands on the Nogais living in the steppes to the north of the peninsula and in the plains of the Crimea itself. Hundreds of carts, horses, sheep and cattle were, for example, requisitioned from the Nogai villagers by the government during the conflict. In addition, Nogai cartsmen and riders were conscripted to transport the wounded to the mainland, carry artillery shells to the front and feed Russian soldiers billeted in their lands. ${ }^{55}$ The Nogais, unlike the local Russian population, however, received very little compensation from the government for their labor and losses and this appears to have seriously disrupted the Nogais' economy. ${ }^{56}$

\section{The Nogai steppe migration of 1860}

In the years following the Russian defeat, Russian sources record the arrival among the Nogai Tatars of itinerant holy men (presumably sufi dervishes) from the Caucasus who circulated throughout the Nogai auls (camps) calling on the faithful to abandon the Dar al-Harb (land of war with the infidels) for the lands of the caliph. ${ }^{57}$ As early as April 1859, Russian settlers in the Kuban (north Caucasian plain) in fact began to notice considerable activity among their Nogai neighbors

54. Robert Walpole, Travels in various countries of the East (London: Longman, Hurst, 1820): 466.

55. Ia. S. Smirnova et al., op. cit.: 39.

56. G. I. Levitskii, art. cit.: 606.

57. Ia. S. Smirnova et al., op. cit.: 39. 
that also point to internal religious calls for emigration. A contemporary source describes the departure of the Nogais as follows:

"Distributed with their families and neighbors among the Russians, with whom the Nogais lived well, events took on a dramatic character. In the Nogai settlements could be heard the crying of women and children. In the cemeteries there was a tremendous scene of farewells at family graves. When the Russian peasants tried to persuade them to stay, the Nogais with tears answered 'No we cannot - everyone is going, it is a sin to stay'." 58

By the summer of 1859 whole villages of Nogais from the Djambulaq and Kuban Hordes were in motion. Eyewitness accounts of this strange migration claim:

"The Nogais unwillingly quit their homeland [...]. In departing we did not, however, see one tear in the eyes of the 90-year-old elders; but many among the Nogais gave sincere farewells to their Russian acquaintances who had resided in the vicinity of their auls as they departed. The women and children, dressed in their best dresses, sat or herded the cattle. The men on horseback were wealthy but those on foot poor." 59

Many of the departing Nogais moved westward across the southern Ukraine and wintered in the steppes to the north of the Crimean peninsula before embarking from the Crimean ports of Feodosiia or Kerch for the Ottoman Empire. Others migrated to the Ottoman province of Dobruca (coastal Romania) via the Buçak steppe which was, by this time, filled with Slavic, Jewish and Moldavian settlers. This trek to the Ottoman Empire was to be Europe's last great migration of the descendants of the Tatar hordes and was to see the virtual disappearance from the steppes of the Kipchak-speaking Turkic nomads that had dominated these plains for close to a millennium. Between 1859 and 1860 as many as 50,000 Nogai herdsmen were to abandon the Kuban and the neighboring district of Stavropol. Prior to this departure (in 1850), the Nogai population of this region was estimated to have been $76,148.60$

The passage of this large contingent of Nogais across the lands of the Tauride province could not but have effected the Nogais of the Crimea and neighboring steppes who were still suffering from impoverishment caused by the Crimean War and from the devastation wrecked on their communities by Cossack marauders. Most noticeably, a group of 16,000 migrating Nogais wintered with their kin in the Melitopol and Berdiansk districts (to the north of the Crimea) in the winter of 18591860. Their prolonged stay in this region appears to have unsettled the Nogais of the Crimean peninsula and steppes regions to the north who probably became alarmed at the Kuban Nogais' stories of the Russian treatment of the Circassians. ${ }^{61}$

58. Ibid.

59. Ibid.: 45 .

60. Ibid.

61. A. Markevich, art. cit.: 397. 
At this time, devastated Circassian refugees from the Caucasus were also being channeled through the ports of Kerch and Feodosiia in the Crimea proper on the way to the Ottoman Empire. The mass abandonment of the Russian Empire by this shattered Muslim people that had been so closely linked to the Crimea for centuries also appears to have spread panic among the Crimean Muslims.

\section{The "Great Migration" of 1860 from the Tauride province}

By the spring of 1860 panic had begun to spread among the Muslim population of the Tauride province. Unsettling rumors spread among the Tatar villages which claimed that the tsar would soon be giving the Crimean Tatars the same choice he had given the defeated Circassians: removal to the interior provinces of the Empire or deportation to the Ottoman Empire.62 Nearly 150,000 Circassians had been expelled to the Russian interior from their coastal-mountain homeland and many Crimean Muslims felt this fate would soon befall them. ${ }^{63}$ In early 1860 the Buyuk Goç (Great Migration) spread to the Crimea and the peninsula's Tatar population began selling their possessions to earn enough capital to survive the journey to the Ottoman Empire. There appears to have been a mixture of sorrow and joy in the Crimea as the oppressed, and increasingly landless, population of Crimean Tatars began preparations to leave for the blessed soil of the caliph.

As the Tauride Tatars began their preparations for departure, bewildered Russian officials were quick to attribute the Crimean Muslims' motives for emigrating to religious fanaticism. An official in 1860 for example wrote:

"The administration of the time was convinced that the emigration of the Tatars was evoked by the Mohammedan clergy which, in every way, agitated for emigration and assured the ignorant masses that the mirzas had sold them to the Russian government which intended to forcefully convert them to Orthodoxy." 64

As it had been with the Caucasian peoples, it appears there were undertones of religious migration or hijra in this migration movement that began in 1860 among the Tauride Muslims. One must not, however, overlook the Crimean Tatars' oppressed situation in the Empire, which stemmed from their loss of land to pomeshchiki or their suffering during the Crimean War, as alternative motives for abandoning their ancient Crimean hearth for the Ottoman Empire.

The migration movement in the Crimea appears to have begun in the Ak Kogekskii, Apskii and Aikish counties of the Feodosiia district and soon spread

62. Ibid.: 395 .

63. Seteney Shami, op. cit.: 40; Seraffetin Terim, Kafkas Tarihinde Abhazlar ve Cerkeslik Mefhumu (Istanbul: Minnetoglu Kitabevi, 1976): 150-157.

64. M. Goldenberg, “Krym i krymskie tatary,” Vestnik Evropy, 6 (1883): 69. 
into the steppes towards Evpatoriia, Simferopol and Perekop from this coastal area. ${ }^{65}$ According to a contemporary source:

"The emigration began in spring of this year. The Tatars as early as winter had decided to abandon the Crimea and they moved to sow and apply for jobs by no later than April 15. From this date the movement became clearly noticeable. At first a solitary wanderer, then a family, and finally a commune aimed for Turkey, selling their belongings, throwing that which could not find a buyer onto the steppe or into a marsh. The emigration grew not by the day, but by the hour." 66

By the summer of 1860, "the movement flared up like a steppe fire, moving from district to district, it became out of control like an avalanche." 67 A Crimean landowner of this era describes the departure of the Crimean peasants of his estate as follows:

"I am not able to recall this event, which reminded me of the expulsion of the Moors from Spain, without sorrow. Cows, oxen and the best sheep were slaughtered mercilessly, salted in casks and left to dry in the sun; horses and camels that were not preserved were given or sold to close neighbors or pomeshchiki for the smallest sum of money. Finished with the animals, the people began to pack things which were necessary for living; all that remained, for example, bulky objects of various sorts or village-economy tools, were thrown away without a care. Then, having fixed a day for departure, a chosen person left for the nearest port city, where a steamboat or sailing vessel had been selected in advance. Finally, they all departed and immediately there was silence in the village where the day before hundreds of voices had been heard. Sending off the inhabitants on our land, from the village of Kopurchi to Evpatoriia, I was a witness to the following scene: as the carts left the village and passed the cemetery, everyone took a handful of soil from the graves of their relatives which was carefully placed in a towel." 68

Several accounts mention the departing Crimean Tatars' ritual of taking soil from the fields of their home village which had been cultivated by their forebears for centuries or from the graves of revered forebears. General Totleben, for example, describes the departure of Crimean Tatar peasants for the local administrative center to obtain emigration passports as follows:

"The Tatars continued to emigrate in crowds, with tears they said farewell to their homeland, taking earth with them from the graves of their fathers, quietly and without murmur they passed through the region and sat before the judge, submitting themselves to all laws and unfamiliar demands of the authorities with remarkable meekness and submission." 69

65. G. I. Levitskii, art. cit.: 625.

66. N. Shcherban', "Pereselenie krymskikh tatar," Russkii vestnik, 30, 11-12 (1860): 38.

67. V. Vozgirin, op. cit.: 334.

68. M. Goldenberg, art. cit.: 73 .

69. E. I. Totleben, art. cit.: 541 . 
As the summer of 1860 waned, the pace of out-migration from the Tauride province accelerated and whole districts, especially in the Nogai-inhabited steppe districts of Evpatoriia, Perekop and areas to the north of Simferopol, began to empty. From throughout the steppes the Nogais began to gather around Sarabuz and to make their way to the Crimea's ports. The majority of these were "devastated peasants dressed in rags."70 The Russian government initially made little effort to halt this migration which, of course, confirmed with the wishes of the highest authorities in the land. A governmental official sent from St. Petersburg to the Crimea to assess this migration (known in the sources only as Gerngross) traveled through the Crimean Tatar countryside declaring that the Crimean Tatars were unproductive and untrustworthy peasants who were to be encouraged to emigrate. ${ }^{71}$ Like many Russian officials, Gerngross stood to personally profit from the departure of the Muslim peasants who occupied prime land in the Crimean peninsula. Markevich claims that, after having encouraged the migration of the Crimean Tatars from the Empire, Gerngross purchased a house and plot of land (presumably at deflated price) in the Tatar village of Buyuk Lambat (Large Lantern) on the southern coast. ${ }^{72}$

Throughout the Crimea, other Russian officials similarly encouraged the peninsula's Muslim population to emigrate from the Empire. Russian officials in the city of Evpatoriia, for example, publicly announced tsar Alexander's decree on the desirability of the Tatars' departure to the accompaniment of drums in the town square. As the emigration movement snowballed, however, the local administration's attitude towards the departure of the Muslim peasantry began to change. It soon became apparent that the Crimea's Muslim population was not emigrating in the thousands, but in the tens of thousands. Russian pomeshchiki in particular became seriously alarmed when whole estates lost their barshchina (tax) paying peasants, and the government itself became concerned when entire tax paying villages and productive districts began to lose their hard-working fieldhands. With the departure of the Crimea's work force, land value in the Crimea plummeted and many Crimean pomeshchiki, who had previously encouraged the departure of the Crimean Tatar peasantry, faced the daunting prospect of financial ruin as a result of the very exodus they had encouraged.

Towards the end of 1860, the Crimean pomeshchiki summoned an urgent allCrimean meeting in Simferopol to discuss this problem that few had foreseen. According to a contemporary source, the Crimean magnates came to the conclusion that the emigration of the Tatars "was costing the state close to 300,000 meek, gentle, submissive, tax-paying subjects. As to the region itself, in the end it will be forever devastated. The Tatars are the only working force in the peninsula." 73 The following account of this extraordinary meeting of Crimean landowners which took

70. B. M. Vol'fson, art. cit.: 190.

71. A. Markevich, art. cit.: 402.

72. Ibid.: 403 .

73. N. Shcherban', art. cit.: 36. 
place towards the end of the summer of 1860 shows how sharply the position of this class towards the Tatars had changed:

"In August 1860 a special, extraordinary meeting of Crimean pomeshchiki was held. There was only one question on the agenda - how to prevent any further Tatar departures. Many tears were shed here concerning the exit of the Tatars who had been treated as 'slouchers' and 'idlers' by these very pomeshchiki. There were bitter arguments as the pomeshchiki blamed one another for exploiting the peasants." 74

Motivated by the pragmatic goal of preventing their own financial ruin, the powerful Crimean pomeshchiki sent an urgent message to St. Petersburg calling for a halt to the issuing of emigration passports to the departing Crimean Tatars. Fear that the emigration movement would spread to the Volga Tatar region also rose at this time and the Russian government saw the continued migration of its Crimean Muslim subjects as a real threat. It is also interesting to note that Russian officials in the Crimea believed that the religious motives for the Crimean Tatar migration were so real that they made an effort at this time to prove that there was no verse in the Qur'an calling for the emigration of Tatars from the Russian Empire. ${ }^{75}$ As the Russian government's policy towards the Crimean Tatars changed, albeit for purely economic reasons, Crimean officials began, at last, to analyze the causes of this mass migration of the hard-working Crimean Muslim class whose value appears to have been underestimated.

\section{Explanations for the migration of $1860-1861$}

By the winter of 1860 the rate of migration had tapered off due to poor conditions associated with traveling across the stormy Black Sea during this season. By the spring of the following year the Russian government had reversed its stance on the issue of the Crimean Tatar emigration and had canceled the distribution of passports to the Muslim population. Although the migration of Crimean Tatars continued in 1861, this movement was much smaller than that of the previous year (only 11,000 departed in this year) and soon tapered off. The decision to halt the migration was taken in order to protect "the landowners of the southern shore and in particular the great princes of the tsarist administration and the governor himself" who feared the migration movement would spread from the steppes to their valued estates on the southern coast. ${ }^{76}$ When calm again returned to the Crimea in late 1861, stunned Russian officials came to the conclusion that the mass emigration of the previous year had cost the Tauride province a full two-thirds of its Tatar pre-war population of approximately 300,000 . It was only by preventing the departure of

74. B. M. Vol'fson, art. cit.: 192.

75. E. I. Totleben, art. cit.: 537.

76. B. M. Vol'fson, art. cit.: 189. 
the south-coast Muslims that this important agricultural element had not participated in the general emigration which had begun to spread to this region in the fall of 1861. It is ironic that a Crimean Tatar presence in the Crimean Dar alHarb (which later provided the seed for the rise of a Crimean Tatar national identity) may have thus been forcefully maintained by Russian pomeshchiki for strictly economic reasons.

In the aftermath of the Great Migration of 1860-1861, Crimean officials began to look for the underlying causes for this movement, which had already begun to have a devastating impact on the peninsula's economy (especially in the Nogai Tatar dominated plains of the northern Crimea). Totleben recorded his findings on the subject after interviewing departing Crimean Muslims and left the following account:

“To the question of 'Why are you leaving?' the Tatars answered:

'I don't know'...'It is necessary to go'.. 'The pomeshchik is bad'...'If they permit us to go, it means go'...' If one goes we should all go'.. 'The district has been hurt'...'The tsar is far off, but the sky is higher'. A kind-hearted elder said to me 'We have eaten Russian bread for 60 years, God give health to the tsar'.'77

As in the past, there was of course interest among Russian officials in the role that religion had played in the Crimean Muslims' decision to leave the Russian Empire for the Ottoman Empire. In his article, Vol'fson stresses the religious factor as a motive for the Tatar migrations. According to this account:

"A wide agitation took place among the Tatars with the assistance of the Muslim
clergy of Turkey. They spread false rumors that the sultan had raised new cities
to which he invited all worshippers of Mohammed, that the sultan would give
the best land without rent fees to settlers, when necessary he would give a pair of
oxen and a horse to be paid for over a ten-year period, that there was free land in
Turkey sufficient for 300,000 people, and that a day's wages there was 3 rubles,
that every settler would receive 14 kopecks a day for a year etc. The Turkish
agents were well dressed, with large amounts of money in their pockets, and
circulated among the cities and countryside relating how 'wonderful' and
'blessed' life was in Turkey. The agitators were helped by the mullahs who
speculated on the religiosity of the ignorant Tatars. The 'infidels are robbing
you' they said 'it is not necessary to endure this any longer, God himself has led
you to resettle in Turkey.' Leading the drive to hijra - the arrival of the
messiah - [sic] the mullahs declared that all those who did not desire to emigrate
to Turkey were 'unbelievers'.' 78

Russian officials were convinced that there were internal reasons within the Crimean Muslim community for the strange departure of the majority of the Crimea's Tatar population (millenarian movements calling for hijra to the lands of the caliph, i.e. "fanaticism") and Markevich states "The agitation of the Turks

77. E. I. Totleben, art. cit.: 541.

78. B. M. Vol'fson, art. cit.: 187-188. 
certainly played a role in this emigration and appeals in the name of the caliph under the Sancak-i Serif (Banner of the Prophet)." 79 A contemporary, Haji Murat Ibrahimbeili, however, remarked that "The propaganda of Turkey and England would not have been effective in influencing the intelligent population if there had not been internal socio-political causes which produced dissatisfaction among the masses of people, tsarism took away land from the local inhabitants, evoking sharp dissatisfaction among them." 80

A Russian landlord of the period points to the same multi-causal roots for the Crimean Tatars' migration even while describing the role of religious figures in calling up this hijra.

"From the start of Spring, Turkish emissaries, mullahs of course, inundated the Crimea and preached among the mosques of all of its cities and villages on the necessity of Muslims to migrate under the banner of the Turkish sultan since, they added, this was declared in the Qur'an. The soil for this propaganda was incredibly fertile. The steppe Tatars were actually horribly oppressed; more than feudal slaves in times past." 81

Totleben concurred stating "It is obvious that all these preceding causes and the totality of the circumstances were enough, in a short period of time, to incite the entire population, without the excitement of fanaticism to which many solely ascribe the migration." 82 In a similar vein, Fisher writes "It seems clear, however, that such 'agitation', even if it was extensive, would have had little chance of success without Russian provocations." 83

The migrations of 1860-1861 may have also been an example of what sociologists call a "stock effect," in which emigration is perpetuated by communication links between those in the new land and those left behind. It must be remembered that the mass migration of approximately 100,000 Crimean Muslims to the Ottoman Empire in 1792, and the smaller out-migrations in the interim (including the departure of between 30,000 and 40,000 emigrants during the Crimean War a mere four years earlier) divided many patriarchal Crimean Tatar Muslim families and traditionally tight-knit villages between the Ottoman and Russian Empires. Contemporary sources mention communication between the Tatar diasporas of the Dobruca and Anatolia on one hand, and the Tatar population of the Crimea on the other. Word of these émigrés' settlement in the Ottoman Empire and their comparative sense of security on the ak toprak (white soil) of the sultan-caliph would have certainly reached relatives and friends in the old homeland, the Crimea. These stories may have been influential in enabling the pre-

79. A. Markevich, art. cit.: 396.

80. Ia. S. Smirnova et al., op. cit.: 40.

81. N. P., "Iz vospominanii byvshego krymskogo pomeshchika," Russkaia starina, 131 (1907): 164.

82. E. I. Totleben, art. cit.: 357.

83. A. Fisher, "Emigration of Muslims...," art. cit.: 361. 
modern Crimean Muslim peasantry to imagine the Memleket-i Islam (Islamic Realm, i.e. the Ottoman Empire) as an alternative homeland. Similarly, when word of the troubles that the 1860 wave of emigrants were facing in the Ottoman Empire reached the Crimea, it acted as a deterrent to further migrations.

\section{Nineteenth-century hijra to the Ottoman Empire}

In his work Kirimli states: "Traditionally, the primary interest of the average Crimean Tatar in Turkey was the religious one, as this was the principal basis of his own self-identification. No doubt, the Ottoman Empire, as seat of the caliph, held a certain mystical significance for him." ${ }^{4}$ After experiencing the devastation of the Crimean War and three quarters of a century of land confiscation, the reports from friends and kin in the idealized lands of the Ottoman caliph would have provided a most powerful incentive for many oppressed mid-nineteenth-century Crimean Muslims to abandon their Russian homeland for the opportunity to live in the Dar al-Islam. For these nineteenth-century muhacirs (religious emigrants), the Ottoman Empire had become an "imagined homeland" and the umma (the ecumenical Islamic body) an "imagined community." Tens of thousands of Crimean Muslims had in fact sold their possessions and followed their ak sakals (lit. "white beards", village elders) and mullahs in a migration that combined both the hope of preserving their community's religious identity and finding salvation in socioeconomic terms in the ak toprak of the sultan.

The muhacir destans (religious-emigrant ballads) which became an integral part of nineteenth-century Crimean Muslim culture are replete with the imagery of Islam and reflect the influence of religion in many Tatars' decision to emigrate to the land of the caliph. Throughout the nineteenth century, Crimean Tatar kedays (traveling bards) sang of the sorrow of migration and captured the panic that swept the Crimean countryside during this dark period. ${ }^{85}$ Ballads from this genre also speak of the veneration the simple Crimean Muslim peasants felt upon arriving in the minaret-studded skyline of Istanbul, the sprawling capital of the sultan. For the nineteenth-century muhacir, the first sight of the sultan's Topkapi palace dominating the bay of Istanbul's Golden Horn, with the towering minarets of the sultan Ahmed Mosque (Blue Mosque), the Suleimaniye Mosque and Hagia Sophia as a backdrop, would have had considerable religious symbolism. Nineteenthcentury accounts report that Circassian immigrants arriving in the sultan's lands in Syria removed their shoes before walking on the holy soil of this region and many Crimean muhacirs would have had a similar feeling of spiritual awe upon arrival on the "white soil" of the Ottoman Empire. ${ }^{86}$

84. Hakan Kirimli, National movements and national identity among the Crimean Tatars (1905-1916) (Leiden: E.J. Brill, 1996): 151.

85. Battal Taymas, "La littérature des Tatars de Crimée," in Philogiae Turcicae Fundamenta (Paris: Aquis Mattiacis Apud Francisum Steiner, 1974): 785-791, here 787.

86. Seteney Shami, op. cit.: 41 . 
The Crimean Tatars and other Russian Muslims were not alone in migrating to the core of the Ottoman Empire during this period. Tens of thousands of Bosniacs (Bosnian Muslims), Albanians, Balkan Turks, and Muslims from lands occupied by European powers, such as Algeria and Tunisia, also migrated to the heartland of the Ottoman Empire during the second half of the nineteenth century. In his article on the nineteenth-century hijra from Russia and the Balkans to the Ottoman Empire, Kemal Karpat writes: "In sum, the Muslims living on the periphery of the empire, who were faced by threats to their cultural existence and material welfare, sought salvation by moving closer to the center - whose attraction and importance had risen in proportion to the weakness of the periphery." 87 For the Crimean and other Islamic emigrants, the migration to the core of the Ottoman Empire was a journey to the center of the Sunni Islamic world and an escape from the encroaching Christian world.

Many muhacir destans from the nineteenth-century Crimea were written in an apocalyptic tone and have their equivalents in songs from the Muslim Balkans after 1878. These songs of departure evoke the sorrow of leaving traditional homelands that are symbolically consumed by fire and disaster with the arrival of Christian (Serbian, Austrian, Romanian, Bulgarian, etc.) rule. In the Crimean context, the destans also speak of the sorrow experienced by simple Crimean Muslim peasants who felt impelled to leave their cherished villages, farms and hereditary stone houses which had been passed on from generation to generation. The following destan, collected from Crimean Tatars by an early twentieth-century Russian anthropologist, is fairly typical of the muhacir destan genre and clearly demonstrates the importance of Islam in nineteenth-century Crimean migrations to the Ottoman Empire.

Let me tell you about the situation in the Crimea,

Neither young woman nor young man remains in her,

They all burn with the longing to migrate to the Islamic lands,

Look down on us God, we are leaving the Crimea!

What a wonderful climate is in the Crimea!

But strife is not solved in her according to the shariah

Why does the Padishah accuse us of rebellion?

Look down on us God, we are leaving the Crimea!

At one time they continually took passports, The officials benefited, but the people were ruined, All Muslims, without exception hurry to acquire passports, Look down on us God, we are leaving the Crimea!

The well-to-do acquire passports without hindrance, The poor people are driven to despair,

87. Kemal Karpat, "The hijra from Russia and the Balkans," in Dale F. Eickelman and James Piscatori, eds, Muslim travellers: Pilgrimage, migration, and the religious imagination (London: Routledge, 1990): 133. 
The mosques and medreses are boarded up,

Look down on us God, we are leaving the Crimea!

Intelligent people have gone to the office places...

[With the hope] that they won't harm the people,

[With the hope] that the government will relate to all equally and will not take up arms against them. ${ }^{88}$

Many of the popular songs of migration that were sung by both the diaspora groups of the Ottoman Empire and those that remained in the Russian Empire are named for the home village in the Crimea of the destan's author. Songs of this sort provide insight into the nineteenth-century Crimean Muslim emigrant's sociology and give a unique insight into their motives for leaving the Crimea. The following destan written by an emigrant from the Crimean village of Socuk Su (Cold Water) in the southern Crimea became particularly popular in Anatolia among emigrants who, having migrated to the Ottoman Empire, found themselves longing for the cherished Yeshil Ada (Green Isle) of the Crimea. While the loss of rhyme in the translation certainly detracts from the ballad's poignant symbolism, its message of longing for the Crimea is clear:

We are setting off on a voyage, having left behind our village,

We know not what we do and we find ourselves lost!

Socuk $\mathrm{Su}$ is famous for its cleft cliffs;

Truly my love, our village was left in vain!

When the wind blows strongly, the leaves blow from the trees;

We were not able to take a handful of soil from our village!

We are setting off, forsaking our village and watching the clouds;

With who will we frolic as the flowers have been scattered?

We do not want to leave, but the pomeshchik said "depart!"

If we happen to die on the sea, our bodies will be devoured by fish!

In Socuk Su there are five apple orchards,

Never before was there such sadness!

Socuk Su's orchards stretch for 100 versts,

From the village abandoned by us, we set off with 100 rubles!

When we sat on the ferry, we were in a panic,

And now we are no longer fit to live in the Crimea!

Socuk Su's fountain...the sea and the ocean,

Let our name remain and call us emigrants!

Glory to mosques and minarets of Istanbul,

Upon embarking on the ferry my head spun;

88. P. V. Maslov et al., Krym. Khrestomatiia po istorii kraia (Simferopol': Krymskoe Gosudarst. Izdatel'stvo, 1930): 240. 
Friends, my sister remains in the Crimea!

The fruit in the garden of the Count is ripening early,

And a fire has descended on the Crimea! 89

Those Crimean Tatars who, after 1861, remained in the Tauride province, which was described in the Ottoman Tatar diaspora as "a land of fire," increasingly found themselves a minority in their own homeland. From a demographic perspective the century-long advance of Slavic settlers into the southern Ukraine at the expense of the indigenous Turco-Muslim population had made a great step forward with this migration. The Crimean Tatars would never again be a majority in their traditional hearth and the Crimea's plains, like those of the Kuban, had been opened up for Slavic colonization.

With the departure of the bulk of the Crimea's Nogai inhabitants, the majority of Crimean Tatars remaining in the Crimean homeland were concentrated in the hills and mountains of the southern Crimea and along the southern shore. Hundreds of steppe villages had been abandoned in the Great Migration and Crimean Tatar life was now centered in small terraced coastal villages, such as Guzruf, Uskut, Tarak Tash, Kizil Tash, Yalta, Alupka, Alushta, Derekoy, Gaspra, Buyuk Lambat, Socuk $\mathrm{Su}$, Simeiz, Sudak or smaller villages in the Yaila hinterland. As the stunned Tatar remnant living in the Crimea's south surveyed the transformation of their homeland resulting from the exodus of 1860-1861, they saw a land that had been fundamentally changed. This was now a Russian land, Russian was the language and culture of the towns and, increasingly, of the countryside in the Crimea as tens of thousands of Slavic peasants from the neighboring mainland provinces of Ekaterinoslav, Kursk, Poltava, Chernigov, Kharkov and Voronezh filled the places vacated by the Nogai emigrants.

Although there were smaller migrations from the Crimea to the Ottoman Empire later in the nineteenth century (most notably in 1874) the size of migration never again reached that of the Great Migration of 1860-1861. By the twentieth century an intelligentsia among the Crimean Tatars came to see the Crimea not as a province in the Russian Empire or "the land of the infidel" but as their people's unique patrimony. To these young nationalists the Crimea was not a place to be abandoned, but a cherished ana yurt (motherland) or milli vatan (national homeland) to which the Crimean Tatar nation had a unique claim. The nationalization of the Crimean Muslim peasant population actually continued during the first two decades of the Soviet period. The Crimean Tatars were considered by Moscow to be the native population of the Crimea with unique rights to this territory which was organized as the Crimean Autonomous Soviet Socialist Republic.

Evidence to the level of territorialization among the Crimean Tatar nation was vividly displayed when this entire people were ethnically cleansed from their homeland in 1944 by Josef Stalin (on the spurious charges of mass treason during

89. S. B. Efetov. and B. I. Filonenko, "Pesni krymskikh tatar," Izvestiia tavricheskogo obshchestva istorii, arkheologii i etnografii (Simferopol'), 1(58) (1927): 69-85, here 71. 
World War II). Far from assimilating among the peoples in their places of exile (mainly in Uzbekistan) the Crimean Tatars waged a 45-year struggle against the Soviet regime to return to their cherished homeland. By 1989 the Soviet government allowed the exiled Crimean Tatars to return to their homeland on the Black Sea. In an ironic reversal of their forebears' out-migration from this very territory, 250,000 Crimean Tatars, out of an estimated CIS population of 500,000, sold their houses and apartments at pittance, left their jobs behind and migrated to an imagined homeland most had never seen. For the secular Crimean Tatar nationalists of today the "re-Tatarization" of the Crimea is seen as closing the circle of forced migration and deportation which began with the Great Migration of 18601861. For today's Crimean Tatars it is the secularly-defined Crimean homeland that is the sacred ak toprak.

University of London

School of Oriental and African Studies

Thornhaugh Street

Russell Square

Bloomsbury

London WC1 OXG

e-mail:bw5@soas.ac.uk 